\title{
Oral care and nosocomial pneumonia: a systematic review
}

\author{
Cuidados bucais e pneumonia nosocomial: revisão sistemática \\ Maria Carolina Nunes Vilela ${ }^{1}$, Gustavo Zanna Ferreira ${ }^{2}$, \\ Paulo Sérgio da Silva Santos ${ }^{2}$, Nathalie Pepe Medeiros de Rezende ${ }^{1}$
}

\begin{abstract}
To perform a systematic review of the literature on the control of oral biofilms and the incidence of nosocomial pneumonia, in addition to assessing and classifying studies as to the grade of recommendation and level of evidence. The review was based on PubMed, LILACS, and Scopus databases, from January 1st, 2000 until December 31st, 2012. Studies evaluating oral hygiene care related to nosocomial infections in patients hospitalized in intensive care units were selected according to the inclusion criteria. Full published articles available in English, Spanish, or Portuguese, which approached chemical or mechanical oral hygiene techniques in preventing pneumonia, interventions performed, and their results were included. After analysis, the articles were classified according to level of evidence and grade of recommendation according to the criteria of the Oxford Centre for Evidence-Based Medicine. A total of 297 abstracts were found, 14 of which were full articles that met our criteria. Most articles included a study group with chlorhexidine users and a control group with placebo users for oral hygiene in the prevention of pneumonia. All articles were classified as B in the level of evidence, and 12 articles were classified as $2 \mathrm{~B}$ and two articles as $2 \mathrm{C}$ in grade of recommendation. It was observed that the control of oral biofilm reduces the incidence of nosocomial pneumonia, but the fact that most articles had an intermediate grade of recommendation makes clear the need to conduct randomized controlled trials with minimal bias to establish future guidelines for oral hygiene in intensive care units.
\end{abstract}

Keywords: Pneumonia, ventilator-associated; Oral hygiene; Chlorhexidine; Intensive care units; Evidence-based practice

\section{RESUMO}

Apresentar revisão sistemática da literatura sobre o controle do biofilme bucal e a incidência da pneumonia nosocomial, avaliando e classificando os estudos quanto ao grau de recomendação e ao nível de evidência científica. A revisão foi realizada nas bases PubMed LILACS e Scopus, de 10 de janeiro de 2000 até 31 de dezembro de 2012. Foram selecionados os estudos que avaliaram os cuidados com higiene bucal relacionando-os com infecções nosocomiais em paciente internados em unidades de terapia intensiva, seguindo os critérios de inclusão. Foram incluídos artigos na íntegra publicados em inglês, espanhol ou português, que abordavam alguma técnica de higiene bucal, química ou mecânica, na prevenção de pneumonia, as intervenções executadas e os resultados. Após análise dos dados, os artigos foram classificados quanto ao nível de evidência e o grau de recomendação, de acordo com os critérios da Oxford Centre for Evidence-Based Medicine. Foram encontrados 297 resumos e, destes, 14 artigos na íntegra contemplaram nossos critérios. A maioria dos artigos incluía um grupo de estudo com uso de clorexidina e um controle com o uso de placebo para higiene bucal na prevenção de pneumonia. Quanto ao nível de evidência, todos os artigos foram classificados como B; quanto ao grau de recomendação, 12 artigos foram classificados como 2B e 2 como 2 C. 0 controle do biofilme bucal reduz a incidência de pneumonia nosocomial, porém o nível de evidência e o grau de recomendação intermediário deixam evidente a necessidade da elaboração de estudos clínicos randomizados controlados com viés mínimo para estabelecer futuros protocolos para higiene bucal em unidades de terapia intensiva.

Descritores: Pneumonia associada à ventilação mecânica; Higiene bucal; Clorexidina; Unidades de terapia intensiva; Prática clínica baseada em evidências

\section{INTRODUCTION}

Nosocomial infections are among the main causes of mortality in seriously ill patients at Intensive Care Units (ICU), and the most frequent infections are urinary, surgical wounds, and pneumonias. ${ }^{(1)}$

\footnotetext{
1 Universidade de São Paulo, São Paulo, SP, Brazil.

2 Faculdade de Odontologia de Bauru, Universidade de São Paulo, Bauru, SP, Brazil.

Corresponding author: Paulo Sérgio da Silva Santos - Rua Dr. Octavio Pinheiro Brisolla, 9-75 - Vila Universitária -Zip Code: 17012-901 - Bauru, SP, Brazil - Phone: (55 14) 3235-8000 - E-mail: paulosss@fob.usp.br

Received on: Sept 17, 2013 - Accepted on: July 21, 2014

DOI: 10.1590/S1679-45082015RW2980
} 
The risk of developing nosocomial pneumonia (NP) increases with the use of mechanical ventilation (MV), and besides prolonging, on average, the length of hospital stay for 5 to 9 days, it rises hospital costs. ${ }^{(2)}$

The mouth of ICU patients can serve as an important reservoir for respiratory pathogens associated with hospital-acquired pneumonia. These data suggest a new view, in which specific procedures for the control of these oral cavity pathogens should be considered in the prevention of NP. ${ }^{(3)}$

Several studies evaluated the efficiency of mouth decontamination in the prevention of nosocomial pneumonia. Two studies did this by means of a systematic literature review, both conducted in 2007, ${ }^{(4,5)}$ but neither showed the level of scientific evidence or the grade of clinical recommendation. There is a great variety in methods used as to the site of development of the investigations and in intervention methods. Essentially, there are two ways to remove dental plaque and its associated microorganisms: (1) by means of mechanical and/or (2) pharmacological interventions. The need to use one of these methods was made evident when studies demonstrated that 48 hours after admission to the ICU, all the patients presented with oropharyngeal colonization by Gram-negative bacilli, which are frequent etiological agents of nosocomial pneumonia-hence, the biofilm is considered an important pool of respiratory pathogens..$^{(2,-6)}$

\section{OBJECTIVE}

To perform a systematic review of literature on the control of oral biofilm and the incidence of nosocomial pneumonia, evaluating and classifying the studies as to the grade of recommendation and level of scientific evidence.

\section{METHODS}

Planning of the systematic review sought to clarify the following guiding question: "can oral hygiene care prevent nosocomial pneumonia in patients under mechanical ventilation at the ICU?"

The selection of articles was done using three databases in the healthcare field: PubMed, LILACS, and Scopus, from January 1st, 2000, to December 31st, 2012, using the following keywords in English combined among themselves: "nosocomial pneumonia", "pneumonia associated with mechanical ventilation", "oral care", "oral hygiene", and "oral microflora".

The studies were selected after careful reading of the title and summary in order to verify if they corresponded to the guiding question. After the initial selection, the material was read in full and chosen when it covered all the following inclusion criteria: availability of the whole article; published in English; that covered some oral, chemical, or mechanical technique in prevention of pneumonia; and information about the characteristics and methodological rigor, interventions studied, and primary results found. The analysis of the articles was made by two investigators in a blind and independent manner.

The analysis of the data extracted was made descriptively, with no meta-analysis and no statistical analysis. The studies were classified as to the grade of evidence and level of significance, according to the Oxford Centre for Evidence-Based Medicine criteria (Charts 1 and 2). ${ }^{(9)}$

Chart 1. Level of Evidence - Oxford Centre for Evidence-Based Medicine

\begin{tabular}{|c|c|c|c|c|c|}
\hline Level & $\begin{array}{c}\text { Therapy/prevention } \\
\text { etiology/damage }\end{array}$ & Prognosis & Diagnosis & $\begin{array}{l}\text { Differential diagnosis/ } \\
\text { prevalence studies }\end{array}$ & Economic/analysis decision \\
\hline $1 \mathrm{a}$ & $\begin{array}{c}\text { SR studies } \\
\text { (homogeneity*)/or RCT }\end{array}$ & $\begin{array}{c}\text { SR* }^{*} \text { studies } \\
\text { (homogeneity*) of cohort studies } \\
\text { with controls from the start of } \\
\text { cases; CDN† with validity in } \\
\text { different populations }\end{array}$ & $\begin{array}{c}\text { SR studies } \\
\text { (homogeneity*) of level } 1 \text { in } \\
\text { diagnostic studies; CDN† } \\
\text { of } 1 \mathrm{~b} \text { studies from different } \\
\text { clinical centers }\end{array}$ & $\begin{array}{c}\text { SR studies } \\
\text { (homogeneity*) or prospective } \\
\text { cohort studies }\end{array}$ & $\begin{array}{l}\text { SR level } 1 \text { studies (homogeneity*) with } \\
\text { economic focus }\end{array}$ \\
\hline $1 b$ & $\begin{array}{l}\text { Individual randomized and } \\
\text { controlled studies with narrow } \\
\text { confidence interval }\end{array}$ & $\begin{array}{l}\text { Individual cohort studies with } \\
>80 \% \text { follow-up; CDN† validated } \\
\text { in a population group }\end{array}$ & $\begin{array}{l}\text { Validation } ¥ \text { of cohort studies } \\
\text { with good } \S \text { reference } \\
\text { standards; CDN† tested in a } \\
\text { single center }\end{array}$ & $\begin{array}{l}\text { Prospective cohort studies with } \\
\text { good follow-up || }\end{array}$ & $\begin{array}{l}\text { Analysis based on clinical costs or } \\
\text { alternative costs } \\
\text { SR* of evidence including sensitivity }^{\text {analyses of various alternatives }}\end{array}$ \\
\hline $1 \mathrm{c}$ & $\begin{array}{l}\text { All died before treatment and } \\
\text { some survived after start of } \\
\text { treatment, but none died during } \\
\text { treatment }\end{array}$ & $\begin{array}{l}\text { All died before treatment and } \\
\text { some survived after start of } \\
\text { treatment, but none died during } \\
\text { treatment }\end{array}$ & $\begin{array}{l}\text { Absolute sensitivity ** } \\
\text { Absolute specificity** }\end{array}$ & All or none in the case series & $\begin{array}{l}\text { Estimative of analysis with absolute } \\
\text { estimate of improvement or worsening t† }\end{array}$ \\
\hline
\end{tabular}


...Continuation

Chart 1. Level of Evidence - Oxford Centre for Evidence-Based Medicine

\begin{tabular}{|c|c|c|c|c|c|}
\hline Level & $\begin{array}{l}\text { Therapy/prevention } \\
\text { etiology/damage }\end{array}$ & Prognosis & Diagnosis & $\begin{array}{l}\text { Differential diagnosis/ } \\
\text { prevalence studies }\end{array}$ & Economic/analysis decision \\
\hline $2 a$ & $\begin{array}{l}\text { SR (homogeneity*) } \\
\text { of cohort studies }\end{array}$ & $\begin{array}{l}\text { SR } \\
\text { (homogeneity*)/ or other } \\
\text { retrospective cohort studies or } \\
\text { group. Control levels of evidence } \\
\text { of the randomized groups of } \\
\text { clinical trials }\end{array}$ & $\begin{array}{c}\text { SR } \\
\text { (homogeneity*) level } 2 \\
\text { diagnostic studies or with } \\
\text { better levels of evidence }\end{array}$ & $\begin{array}{c}\text { SR } \\
\text { (homogeneity* }) \text { of } 2 \mathrm{~b} \text { and }^{\text {studies with better levels of }} \\
\text { evidence }\end{array}$ & $\begin{array}{c}\text { SR (homogeneity*) } \\
\text { of studies with economic focus with } \\
\text { level of evidence } 2 \text { or with better levels } \\
\text { of evidence }\end{array}$ \\
\hline $2 b$ & $\begin{array}{l}\text { Individual cohort studies (including } \\
\text { low quality randomized studies, } \\
\text { that is, }<80 \% \text { of follow-up) }\end{array}$ & $\begin{array}{l}\text { Retrospective cohort studies } \\
\text { or of follow-up of control group } \\
\text { patients treated by randomized } \\
\text { clinical trials; derived from CDN† } \\
\text { that used regression analysis } \ddagger \ddagger\end{array}$ & $\begin{array}{l}\text { Exploratory cohort studies } \\
\neq \text { with good } \S \text { reference } \\
\text { standard (gold standard); } \\
\text { derived from CDN† With } \\
\text { regression analysis of } \\
\text { data } \neq \ddagger\end{array}$ & $\begin{array}{l}\text { Retrospective cohort studies, or } \\
\text { with poor follow-up }\end{array}$ & $\begin{array}{l}\text { Analysis based on costs or limited } \\
\text { alternatives of review of simple } \\
\text { study evidence, including analysis of } \\
\text { sensitivity of various alternatives }\end{array}$ \\
\hline $2 c$ & $\begin{array}{c}\text { Outcome studies; ecological } \\
\text { studies }\end{array}$ & Outcome studies & & Ecological studies & Outcome or auditing studies \\
\hline $3 a$ & $\begin{array}{l}\text { SR (homogeneity*) of } \\
\text { case-control studies }\end{array}$ & & $\begin{array}{c}\text { SR } \\
\text { (homogeneity*) of 3b }\end{array}$ & $\begin{array}{c}\text { SR } \\
\text { (homogeneity }{ }^{*} \text { of } 3 b\end{array}$ & $\begin{array}{l}\text { SR (homogeneity*) } \\
\text { of } 3 \mathrm{~b}\end{array}$ \\
\hline $3 b$ & Individual case-control studies & & $\begin{array}{l}\text { Nonconsecutive studies or } \\
\text { without applying the gold } \\
\text { standard of reference }\end{array}$ & $\begin{array}{c}\text { Nonconsecutive cohort study or } \\
\text { very limited population }\end{array}$ & $\begin{array}{c}\text { Analysis based on limited cost } \\
\text { alternatives, data from very poor } \\
\text { estimates, but incorporating sensitivity } \\
\text { analysis }\end{array}$ \\
\hline 4 & $\begin{array}{c}\text { Case series (or cohort studies } \\
\text { with poor quality or case } \\
\text { control-studies } \S \S)\end{array}$ & $\begin{array}{l}\text { Series of cases (with poor } \\
\text { prognostic quality), cohort } \\
\text { studies }\end{array}$ & $\begin{array}{l}\text { Case-control studies that } \\
\text { depend on the gold standard }\end{array}$ & $\begin{array}{l}\text { Series of cases or studies that } \\
\text { substitute the gold standard }\end{array}$ & $\begin{array}{l}\text { Decision analysis with sensitivity } \\
\text { analysis }\end{array}$ \\
\hline 5 & $\begin{array}{l}\text { Opinion of specialists without } \\
\text { specifying a critical evaluation } \\
\text { or one based on studies of } \\
\text { physiology or initial principles }\end{array}$ & $\begin{array}{c}\text { Opinion of specialists without } \\
\text { specifying a critical evaluation or } \\
\text { based on studies of physiology or } \\
\text { initial principles }\end{array}$ & $\begin{array}{c}\text { Opinion of specialists } \\
\text { without specifying a critical } \\
\text { evaluation or based on } \\
\text { studies of physiology or of } \\
\text { initial principles }\end{array}$ & $\begin{array}{l}\text { Opinion of specialists without } \\
\text { specifying a critical evaluation or } \\
\text { based on studies of physiology } \\
\text { or of initial principles }\end{array}$ & $\begin{array}{l}\text { Opinion of specialists without } \\
\text { specifying a critical evaluation or based } \\
\text { on studies of physiology or of initial } \\
\text { principles }\end{array}$ \\
\hline
\end{tabular}

SR: systematic reviews; RCT: randomized clinical trials; CDN: clinical decision norms; ${ }^{*}$ Systematic review (SR), with homogeneity, means to be free of heterogeneous variation. $\dagger$ Clinical decision norms (CDN) represented graphically by algorithms or score systems, which provide an estimate of diagnosis or prognosis. ‡ Validating specific diagnostic tests previously based on evidence, studies with data collection and analysis (using regression analysis) to find factors that may be considered significant. § Good standard - called the "gold standard", are independent tests applied blindly and objectively to all patients. || Good follow-up (> 80\%) in studies with differential diagnosis, with adequate follow-up time: in an acute situation (1-6 months) and in chronic cases (1-5 years). ๆ When all the patients died before undergoing treatment, but now some survive with the start of treatment, or when some patients died before treatment became available, but none died during the treatment.** There is absolute specificity (negative result) when it excludes the diagnosis. There is absolute sensitivity (positive test) when the test defines the diagnosis. $\dagger+$ Estimates of treatments of better value are clearly those that have low costs. The estimate of a lower value treatment may be a good option, but more expensive; it can also be a bad option with equal costs or even more expensive. 执 Validation studies test the quality of a specific diagnosis, based on prior evidence. An exploratory study collects data and uses regression analysis to identify factors that might be significant. §§ Cohort studies (with poor quality) failed in defining the comparison between the groups and/or failed in measuring exposure and outcome (they should preferentially be blinded); they failed to identify the control group and confounding factors; the follow-up was not sufficiently long to evaluate the outcome; the follow-up of the patients was not complete. Case-control studies (with poor quality) failed to clearly define the comparison between the groups, failed to measure exposure and outcome (preferentially should be blinded), failed to identify the control group and confounding factors. ${ }^{* * *}$ Cohort studies, with focus on diagnosis are considered poor in quality when there is bias in sample selection; measurement of outcome occurs only in $<80 \%$ of the patients that conclude the study; when the outcomes are determined, but not blinded, and there is no objectivity or correction of confounding factors.

Chart 2. Grade of Recommendation Oxford Centre for Evidence-Based Medicine

\begin{tabular}{|c|c|}
\hline A & $\begin{array}{l}\text { Consists in level } 1 \text { studies. A study with strong recommendation in choice; } \\
\text { levels of evidence for routinely recommending medical management are } \\
\text { excellent. The benefits outweigh the damage. There is good evidence to } \\
\text { support the recommendation. }\end{array}$ \\
\hline B & $\begin{array}{l}\text { Consists in levels } 2 \text { and } 3 \text { studies or generalization of level } 1 \text { studies. A study } \\
\text { that recommends the action; significant evidence is found in the outcome, } \\
\text { and the conclusion that there is benefit in the choice of the action relative } \\
\text { to the risks of the damage. There is reasonable evidence to support the } \\
\text { recommendation. }\end{array}$ \\
\hline C & $\begin{array}{l}\text { Consists of level } 4 \text { studies or generalization of levels } 2 \text { or } 3 \text { studies. Finds } \\
\text { minimal satisfactory evidence in outcome analysis, but concluded that the } \\
\text { benefits and the risks of the procedure do not justify generalization of the } \\
\text { recommendation. There is insufficient evidence, whether against or in favor. }\end{array}$ \\
\hline D & $\begin{array}{l}\text { Consists of level } 5 \text { studies or any inconclusive study. Studies with poor quality. } \\
\text { There is evidence to discard the recommendation. }\end{array}$ \\
\hline
\end{tabular}

\section{RESULTS}

Of the 297 summaries first found, 14 articles met the criteria established in this systematic review (Figure 1). Most of the articles included a study group with the use of chlorhexidine and a control group with the use of a placebo. Nine articles concluded that the use of topical chlorhexidine reduced the incidence of NP. Four articles still had not determined statistically significant differences among the groups. Nevertheless, one observed a delay in the establishment of the NP, and another studied toothless patients. As to level of evidence, all the articles were classified as B; as to grade of recommendation, 12 articles were classified as $2 \mathrm{~B}$ and two articles as 2C (Table 1). 


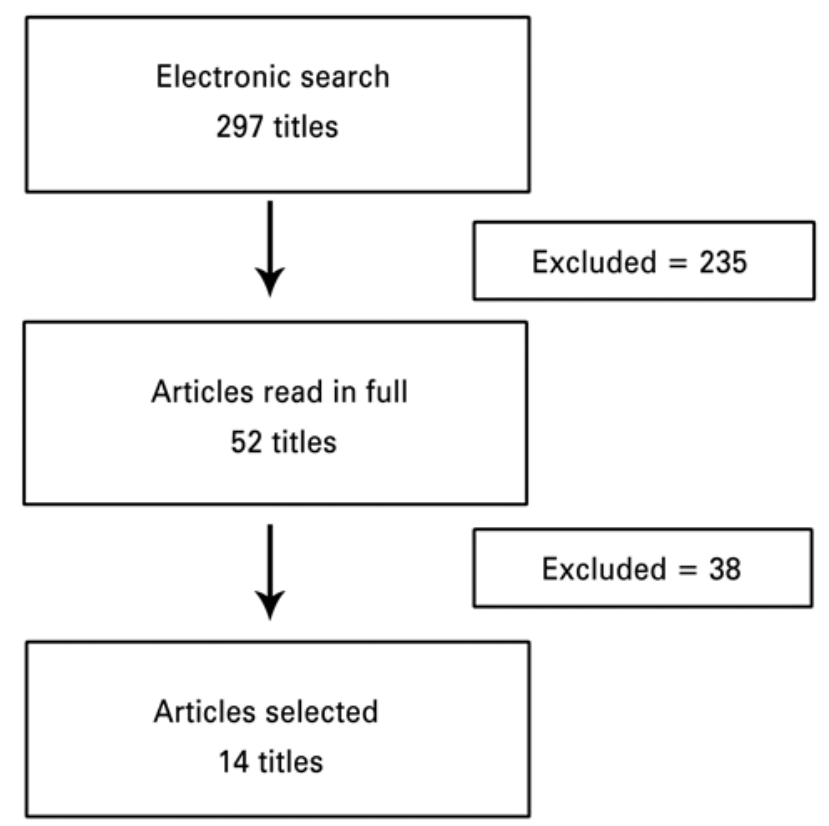

Figure 1. Flow chart of the search strategy

Table 1. Description of the articles included in this review

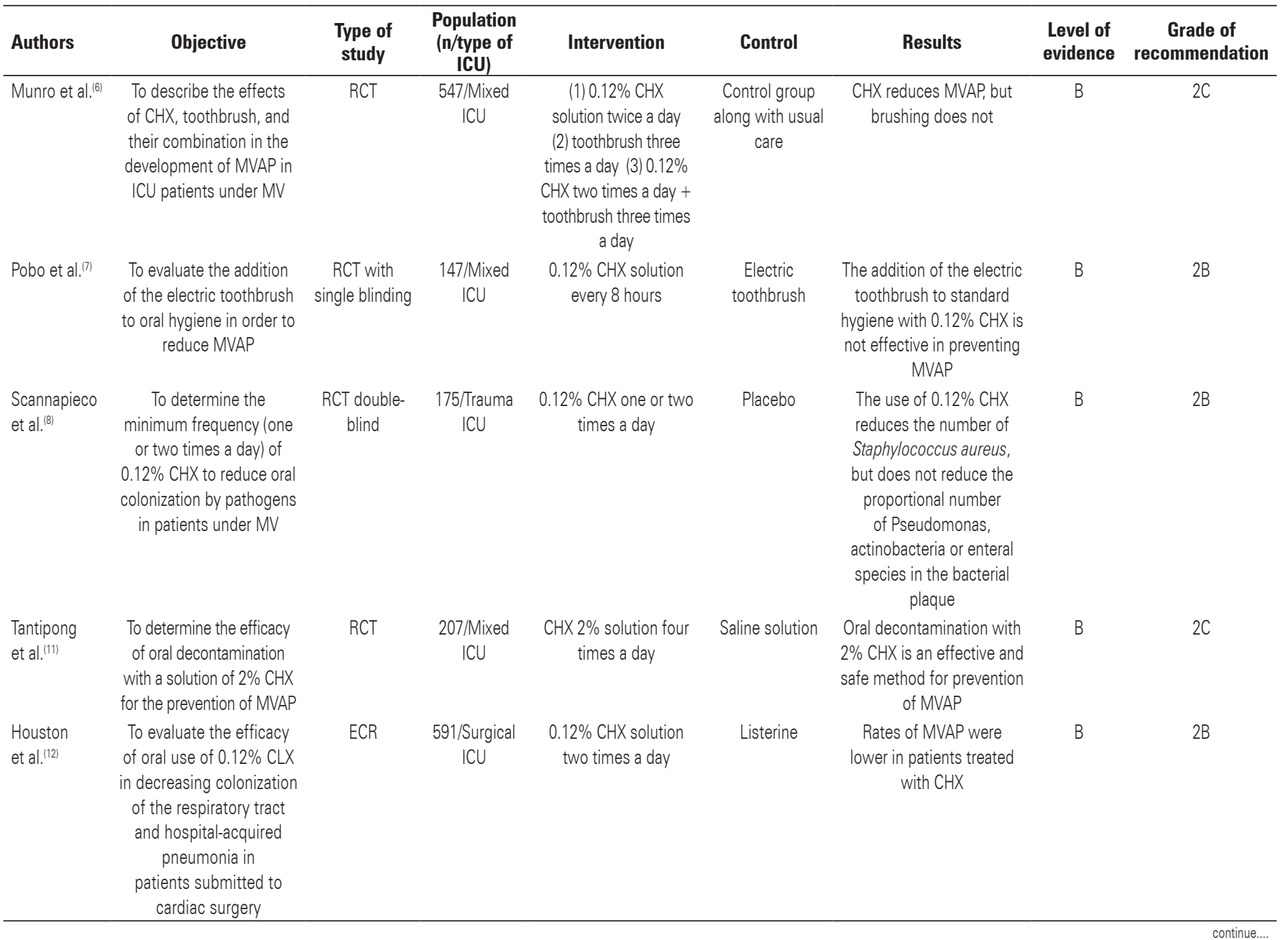


.... Continuation

Table 1. Description of the articles included in this review

\begin{tabular}{|c|c|c|c|c|c|c|c|c|}
\hline Authors & Objective & $\begin{array}{l}\text { Type of } \\
\text { study }\end{array}$ & $\begin{array}{l}\text { Population } \\
\text { (n/type of } \\
\text { ICU) }\end{array}$ & Intervention & Control & Results & $\begin{array}{l}\text { Level of } \\
\text { evidence }\end{array}$ & $\begin{array}{l}\text { Grade of } \\
\text { recommendation }\end{array}$ \\
\hline Grap et al.(13) & $\begin{array}{l}\text { To document the efficacy } \\
\text { of a single application } \\
\text { of } \mathrm{CHX} \text { in the oral } \\
\text { cavity immediately after } \\
\text { intubation on the oral } \\
\text { microbiota and MVAP }\end{array}$ & $\mathrm{RCT}$ & 34/Mixed ICU & $\begin{array}{l}0.12 \% \mathrm{CHX} \text { solution } \\
\text { two times a day }\end{array}$ & $\begin{array}{c}\text { Usual care } \\
\text { Bicarbonate four } \\
\text { times a day }\end{array}$ & $\begin{array}{l}\text { Use of CHX during } \\
\text { post-intubation may } \\
\text { attenuate or retard the } \\
\text { development of MVAP }\end{array}$ & $B$ & $2 B$ \\
\hline $\begin{array}{l}\text { Belissimo- } \\
\text { Rodrigues } \\
\text { et al. }{ }^{(14)}\end{array}$ & $\begin{array}{c}\text { To evaluate the efficacy } \\
\text { of the oral application } \\
\text { of a solution of } 0.12 \% \\
\mathrm{CHX} \text { for the prevention } \\
\text { of respiratory infection in } \\
\text { the ICU }\end{array}$ & $\begin{array}{l}\text { RCT double- } \\
\text { blind }\end{array}$ & $\begin{array}{l}\text { 194/Mixed } \\
\text { ICU }\end{array}$ & $\begin{array}{l}0.12 \% \text { CHX solution } \\
\text { three times a day }\end{array}$ & Placebo & $\begin{array}{c}0.12 \% \text { CHX does not } \\
\text { impede respiratory tract } \\
\text { infection, but can retard its } \\
\text { appearance }\end{array}$ & $B$ & $2 B$ \\
\hline $\begin{array}{l}\text { Lorente } \\
\text { et al. }{ }^{(15)}\end{array}$ & $\begin{array}{l}\text { Comparar a incidência } \\
\text { de PAVM de pacientes } \\
\text { críticos que receberam } \\
\text { cuidados bucais com e } \\
\text { sem escovação manual } \\
\text { dos dentes }\end{array}$ & $\mathrm{RCT}$ & $\begin{array}{l}\text { 436/Mixed } \\
\text { ICU }\end{array}$ & $\begin{array}{l}\text { Group A corresponded } \\
\text { to } 0.12 \% \mathrm{CHX} \text { without } \\
\text { mechanical brushing } \\
\text { Group B corresponded } \\
\text { to } 0.12 \% \mathrm{CHX} \text { with } \\
\text { mechanical brushing }\end{array}$ & & $\begin{array}{c}\text { There were no statistically } \\
\text { significant results }\end{array}$ & $B$ & $2 B$ \\
\hline $\begin{array}{l}\text { Fourrier } \\
\text { et al. }{ }^{(16)}\end{array}$ & $\begin{array}{l}\text { To compare the incidence } \\
\text { of MVAP in critically ill } \\
\text { patients who received } \\
\text { oral care with and without } \\
\text { manual brushing of the } \\
\text { teeth }\end{array}$ & $\begin{array}{l}\text { RCT with } \\
\text { single blinding }\end{array}$ & 60/Mixed ICU & $\begin{array}{l}0.2 \% \text { CHX gel three } \\
\text { times a day }\end{array}$ & $\begin{array}{c}\text { Usual care } \\
\text { Bicarbonate four } \\
\text { times a day }\end{array}$ & $\begin{array}{l}\text { Decontamination with } 0.2 \\
\% \mathrm{CHX} \text { decreased oral } \\
\text { bacterial colonization and } \\
\text { can reduce the incidence } \\
\text { of infections in patients } \\
\text { under MV in the ICU }\end{array}$ & $B$ & $2 \mathrm{~B}$ \\
\hline $\begin{array}{l}\text { Fourrier } \\
\text { et al. }{ }^{[17\rangle}\end{array}$ & $\begin{array}{l}\text { To document the efficacy } \\
\text { of decontamination of the } \\
\text { dental plaque and oral } \\
\text { cavity with use of } \mathrm{CHX} \\
\text { on the rates of hospital- } \\
\text { acquired bacteremia and } \\
\text { respiratory infections } \\
\text { acquired in the ICU }\end{array}$ & $\begin{array}{l}\text { RCT double- } \\
\text { blind }\end{array}$ & $\begin{array}{l}\text { 228/Mixed } \\
\text { ICU }\end{array}$ & $\begin{array}{l}0.2 \% \text { CHX gel three } \\
\text { times a day }\end{array}$ & Placebo & $\begin{array}{l}\text { Decontamination of } \\
\text { bacterial plaque and } \\
\text { gums with } \mathrm{CHX} \text { reduced } \\
\text { the colonization of the } \\
\text { oropharynx by aerobic } \\
\text { pathogens in ventilated } \\
\text { patients, but was } \\
\text { insufficient in reducing } \\
\text { respiratory infections }\end{array}$ & $\mathrm{B}$ & $2 \mathrm{~B}$ \\
\hline $\begin{array}{l}\text { Panchabhai } \\
\text { et al. } .^{(18)}\end{array}$ & $\begin{array}{l}\text { To evaluate if } 0.2 \% \mathrm{CHX} \\
\text { reduces the incidence of } \\
\text { MVAP in the ICU }\end{array}$ & $\mathrm{RCT}$ & $\begin{array}{l}\text { 512/General } \\
\text { ICU }\end{array}$ & $\begin{array}{c}0.2 \% \text { CHX solution two } \\
\text { times a day }\end{array}$ & $\begin{array}{c}0.01 \% \\
\text { potassium } \\
\text { permanganate }\end{array}$ & $\begin{array}{l}\text { The use of } 0.2 \% \text { CHX did } \\
\text { not reduce the incidence } \\
\text { of NP in ICU patients, but } \\
\text { meticulous oral cleaning } \\
\text { decreased the risk of } \\
\text { developing it }\end{array}$ & $B$ & $2 \mathrm{~B}$ \\
\hline Berry et al..(19) & $\begin{array}{l}\text { To test two oral hygiene } \\
\text { strategies on the effects } \\
\text { of microbial colonization } \\
\text { of the dental plaque with } \\
\text { respiratory pathogens } \\
\text { (primary result) and } \\
\text { incidence of pneumonia } \\
\text { associated with } \\
\text { mechanical ventilation } \\
\text { (secondary outcome) }\end{array}$ & $\begin{array}{l}\text { RCT double- } \\
\text { blind }\end{array}$ & $\begin{array}{l}\text { 225/Mixed } \\
\text { ICU }\end{array}$ & $\begin{array}{c}\text { Group B corresponded } \\
\text { to sodium bicarbonate } \\
\text { Group C corresponded } \\
\text { to } 0.2 \% \mathrm{CHX} \text { two times } \\
\text { a day and irrigation with } \\
\text { sterile water* }\end{array}$ & $\begin{array}{c}\text { Group A } \\
\text { corresponded to } \\
\text { sterile water }\end{array}$ & $\begin{array}{c}\text { There was no significant } \\
\text { difference between the } \\
\text { groups }\end{array}$ & $B$ & $2 C$ \\
\hline $\begin{array}{l}\text { Özçaka } \\
\text { et al. }{ }^{(20)}\end{array}$ & $\begin{array}{l}\text { To evaluate if oral scraping } \\
\text { with } 0.2 \% \mathrm{CHX} \text { decreases } \\
\text { the risk of MVAP in } \\
\text { patients in the ICU }\end{array}$ & $\begin{array}{l}\text { RCT double- } \\
\text { blind }\end{array}$ & $\begin{array}{c}\text { 66/ } \\
\text { Respiratory } \\
\text { ICU }\end{array}$ & $0.2 \% \mathrm{CHX}$ solution & Saline solution & $\begin{array}{l}\text { The development rate of } \\
\text { pneumonia in the control } \\
\text { group was greater than in } \\
\text { the study group }\end{array}$ & $B$ & $2 \mathrm{~B}$ \\
\hline $\begin{array}{l}\text { Koeman } \\
\text { et al. }{ }^{(21)}\end{array}$ & $\begin{array}{l}\text { To determine the effect } \\
\text { of decontamination of } \\
\text { the oral cavity with } \mathrm{CHX} \\
\text { or } \mathrm{CHX}+\text { colistin on the } \\
\text { incidence of MVAP }\end{array}$ & $\begin{array}{l}\text { RCT double- } \\
\text { blind }\end{array}$ & $\begin{array}{l}\text { 257/Mixed } \\
\text { ICU }\end{array}$ & $\begin{array}{c}2 \% \mathrm{CHX}(1) \mathrm{CHX}+ \\
\text { colistin (2) }\end{array}$ & Placebo & $\begin{array}{l}\text { Topical decontamination } \\
\text { with } \mathrm{CHX} \text { or } \mathrm{CHX}+\text { colistin } \\
\text { reduces the incidence of } \\
\text { MVAP }\end{array}$ & $B$ & $2 \mathrm{~B}$ \\
\hline
\end{tabular}

*All the patients had their teeth brushed with brushes and tooth paste. ICU: intensive care unit; CHX: chlorhexidine; MVAP: mechanical ventilation-associated pneumonia; MV: mechanical ventilation; RCT: randomized clinical trial; HAI: hospital-acquired infection; NP: nosocomiaal pneumonia. 


\section{DISCUSSION}

Various aspects compromise mouth hygiene in ICU patients favoring microbial growth, such as difficulty and/or impossibility of self-care, presence of the orotracheal tube, which hinders access to the mouth, and the consequent formation of the biofilm and dental plaque. ${ }^{(10)}$ Thus, mouth decontamination takes on extreme importance in preventing nosocomial pneumonia of patients in the ICU.(2) However, there are many methods used besides the diversity of centers in which the studies are carried out, which makes the adequate interpretation and use of intervention methods difficult.

Chlorhexidine is a wide-spectrum cationic antiseptic agent that includes Gram-negative and Gram-positive bacterial, such as oxacillin-resistant Staphylococcus aureus and vancomycin-resistant Enterococcus sp., which may persist chemically active in tissues for up to 6 hours. ${ }^{(11,22)}$ In literature, there is a great variety of treatment regimens using chlorhexidine, including variations in concentration: $0.12 \%,,^{(6-8,14-15)} 0.2 \%,{ }^{(16-20)}$ and $2 \% .^{(11,21)}$ No study evaluated in this review performed comparisons correlating the different concentrations of chlorhexidine and the incidence of nosocomial pneumonia. The most studied solution was $0.12 \%$ chlorhexidine (7 of 14 studies), and in some articles, it served as control for another method of evaluation. ${ }^{(7,15)}$ The $2 \%$ concentration was the most effective in preventing NP, but only two studies evaluated this concentration - one of them, as study with a $2 \mathrm{C}$ level of recommendation.

Some articles compared isolated chemical removal using $0.12 \%$ chlorhexidine, and associated with mechanical removal using an electric and manual toothbrush. ${ }^{(6,7,15)}$ The results of the addition of dental brushing were not significant for the prevention of $\mathrm{MV}$-associated pneumonia. Tooth brushing alone did not reduce pneumonia associated with mechanical ventilation; the combination of brushing with chlorhexidine also showed no additional benefits when compared to the use of chlorhexidine alone. Additionally, during brushing, dislocation of the dental plaque may occur, supplying a large number of microorganisms translocated from the mouth to the subglottic secretions of the lungs, contraindicating the mechanical removal of bacterial plaque with dental brushes, with recommendation only for chemical removal with $0.12 \%$ chlorhexidine. ${ }^{(6)}$

The diversity of patients and of ICUs is an important factor that should be considered in the analysis of NP incidence, taking into consideration the type of ICU and the profile of the patients. The percentage of NP varied from a minimum of $7 \%$ in a group that used mechanical brushing to control biofilm ${ }^{(15)}$ to a maximum of $68.8 \%$ in the control group. ${ }^{(20)}$ A reduction superior to $40 \%$ in incidence of pneumonia was found in five studies, ${ }^{(6,9,14,18,19)}$ but only one article $^{(17)}$ showed an elevation in the incidence of NP $(17.5 \%$ in the placebo group versus $18.4 \%$ of the treated group).

\section{CONCLUSION}

The control of oral biofilm reduces the incidence of nosocomial pneumonia. Oral hygiene using a $0.12 \%$ solution of chlorhexidine, and not dental brushing, seems to be the most effective hygiene method. This concentration of chlorhexidine does not harm the oral mucosa and no dislocation of the dental biofilm towards the posterior oropharynx occurs when mechanical brushing is done.

The fact that most of the articles presented an intermediate B and 2B level of evidence and grade of recommendation, respectively, makes clear the need for conducting randomized controlled clinical trials with a minimal bias, due to the need for intensive care services having at their disposal valid protocols for the effective application of oral care and consequent reduction of nosocomial pneumonia.

\section{REFERENCES}

1. David C. Infecção em UTI. Medicina (Ribeirão Preto). 1998;31:337-48.

2. Amaral SM, Cortês Ade Q, Pires FR. Nosocomial pneumonia: importance of the oral environment. J Bras Pneumol. 2009;35(11):1116-24. Review.

3. Oliveira L, Carneiro P, Fischer RG, Tinoco E. A presença de patógenos respiratórios no biofilme bucal de pacientes com pneumonia nosocomial. Rev Bras Ter Intensiva. 2007;19(4):428-33.

4. Chlebicki MP, Safdar N. Topical chlorhexidine for prevention of ventilatorassociated pneumonia: a meta-analysis. Crit Care Med. 2007;35(2):595-602.

5. Chan EY, Ruest A, Meade MO, Cook DJ. Oral decontamination for prevention of pneumonia in mechanically ventilated adults: systematic review and metaanalysis. BMJ. 2007;334(7599):889. Review.

6. Munro CL, Grap MJ, Jones DJ, McClish DK, Sessler CN. Chlorhexidine, toothbrushing, and preventing ventilator-associated pneumonia in critically ill adults. Am J Crit Care. 2009;18(5):428-37; quiz 438.

7. Pobo A, Lisboa T, Rodriguez A, Sole R, Magret M, Trefler S, Gómez F, Rello J; RASPALL Study Investigators. A randomized trial of dental brushing for preventing ventilator-associated pneumonia. Chest. 2009;136(2):433-9.

8. Scannapieco FA, Yu J, Raghavendran K, Vacanti A, Owens SI, Wood K, et al. A randomized trial of chlorhexidine gluconate on oral bacterial pathogens in mechanically ventilated patients. Crit Care. 2009;13(4):R117.

9. University of Oxford. Centre for Evidence-Based Medicine (CEBM). Oxford Centre for Evidence-based Medicine - Levels of Evidence (March 2009) [Internet]. 2009 [cited 2014 Jule 14]. Available from: http://www.cebm.net/ index.aspx?0 $=1025$

10. Beraldo CC, Andrade D. Oral hygiene with chlorhexidine in preventing pneumonia associated with mechanical ventilation. J Bras Pneumol. 2008;34(9):707-14. Review. 
11. Tantipong H, Morkchareonpong C, Jaiyindee S, Thamlikitkul V. Randomized controlled trial and meta-analysis of oral decontamination with $2 \%$ chlorhexidine solution for the prevention of ventilator-associated pneumonia. Infect Control Hosp Epidemiol. 2008;29(2):131-6.

12. Houston S, Hougland P, Anderson JJ, LaRocco M, Kennedy V, Gentry LO. Effectiveness of $0.12 \%$ chlorhexidine gluconate oral rinse in reducing prevalence of nosocomial pneumonia in patients undergoing heart surgery. Am J Crit Care. 2002;11(6):567-70.

13. Grap MJ, Munro CL, Elswick RK Jr, Sessler CN, Ward KR. Duration of action of a single, early oral application of chlorhexidine on oral microbial flora in mechanically ventilated patients: a pilot study. Heart Lung. 2004;33(2):83-91.

14. Bellissimo-Rodrigues F, Bellissimo-Rodrigues WT, Viana JM, Teixeira GC, Nicolini $E$, Auxiliadora-Martins $M$, et al. Effectiveness of oral rinse with chlorhexidine in preventing nosocomial respiratory tract infections among intensive care unit patients. Infect Control Hosp Epidemiol. 2009;30(10):952-8.

15. Lorente L, Lecuona $M$, Jiménez $A$, Palmero $S$, Pastor $E$, Lafuente $N$, et al. Ventilator-associated pneumonia with or without toothbrushing: a randomized controlled trial. Eur J Clin Microbiol Infect Dis. 2012;31(10):2621-9.

16. Fourrier F, Cau-Pottier E, Boutigny $H$, Roussel-Delvallez $M$, Jourdain $M$, Chopin C. Effects of dental plaque antiseptic decontamination on bacterial colonization and nosocomial infections in critically ill patients. Intensive Care Med. 2000;26(9):1239-47.

17. Fourrier F, Dubois D, Pronnier P, Herbecq P, Leroy O, Desmettre T, Pottier-Cau
E, Boutigny H, Di Pompéo C, Durocher A, Roussel-Delvallez M; PIRAD Study Group. Effect of gingival and dental plaque antiseptic decontamination on nosocomial infections acquired in the intensive care unit: a double-blind placebo-controlled multicenter study. Crit Care Med. 2005;33(8):1728-35.

18. Panchabhai TS, Dangayach NS, Krishnan A, Kothari VM, Karnad DR. Oropharyngeal cleansing with $0.2 \%$ chlorhexidine for prevention of nosocomial pneumonia in critically ill patients: an open-label randomized trial with $0.01 \%$ potassium permanganate as control. Chest. 2009;135(5):1150-6.

19. Berry AM, Davidson PM, Masters J, Rolls K, Ollerton R. Effects of three approaches to standardized oral hygiene to reduce bacterial colonization and ventilator associated pneumonia in mechanically ventilated patients: a randomised control trial. Int J Nurs Stud. 2011;48(6):681-8.

20. Özçaka Ö, Başoğlu OK, Buduneli N, Taşbakan MS, Bacakoğlu F, Kinane DF. Chlorhexidine decreases the risk of ventilator-associated pneumonia in intensive care unit patients: a randomized clinical trial. J Periodontal Res. 2012;47(5):584-92.

21. Koeman M, van der Ven AJ, Hak E, Joore HC, Kaasjager K, de Smet AG, et al. Oral decontamination with chlorhexidine reduces the incidence of ventilatorassociated pneumonia. Am J Respir Crit Care Med. 2006;173(12):1348-55.

22. Senol G, Kirakli C, Halilcolar H. In vitro antibacterial activities of oral care products against ventilator-associated pneumonia pathogens. Am J Infect Control. 2007;35(8):531-5. 